

\title{
Geospatial technology applied to the identification of groundwater recharge areas in northeastern São Paulo, Brazil (doi:10.4136/ambi-agua.83)
}

\section{Nelson Wellausen Dias ; Hélio Nóbile Diniz² ; Marcelo dos Santos Targa ${ }^{3}$; Getulio Teixeira Batista ${ }^{4}$}

\author{
${ }^{1}$ Faculty of Environmental Science, University of Taubaté \\ Email: nelson.dias@unitau.br \\ ${ }^{2}$ Geologist of the Geologic Institute of the State of São Paulo \\ Email: heliodiniz@igeologico.sp.gov.br \\ ${ }^{3}$ Faculty and Director of the Graduate Program in Environmental Science, University of Taubaté \\ Email: mtarga@unitau.br \\ ${ }^{4}$ Faculty of Environmental Science, University of Taubaté \\ Email: getulio@agro.unitau.br
}

\begin{abstract}
Groundwater resource information is crucial for the establishment of protective measures by police makers and local managers. This article presents the findings of a research based on the application of remote sensing technology and auxiliary data for the identification of groundwater recharge areas in the Paraíba do Sul river basin, State of São Paulo, Brazil. The objective of this study was to develop a series of georreferenced geologic information and a sequence of hydrogeologic analysis to determine the location and distribution of recharge areas for future conservation purposes. The results indicate the distribution of five categories of potential recharge areas based on lineament characteristics, fracture bundles, and fracture density analysis. The top three categories should be considered as having the higher percolation quality and infiltration capacity, therefore higher potential for groundwater recharge. Significantly different results were obtained for the two major portions of the study area, crystalline rocks and unconsolidated sedimentary material, this fact hampered the development of hydrogeologic correlations for the entire basin. Results may help policy makers and managers in the development and implementation of an aquifer protection zoning program and local community activities in environmental education and conservationist interventions.
\end{abstract}

Keywords: groundwater recharge; regional hydrogeology; water conservation; remote sensing.

\section{Tecnologia geoespacial aplicada na identificação de áreas de recarga de águas subterrâneas no nordeste de São Paulo, Brasil}

\section{RESUMO}

Informações sobre recursos hídricos subterrâneos são cruciais para o estabelecimento de medidas protetoras por parte dos gestores locais. Este artigo apresenta os resultados de uma pesquisa baseada na aplicação da tecnologia de sensoriamento remoto com dados auxiliares para a identificação de áreas de recarga do aquífero da bacia do rio Paraíba do Sul no Estado de São Paulo. O objetivo do estudo foi desenvolver uma série de informações geológicas georreferenciadas e uma sequência de análises hidrogeológicas para determinar a localização e a distribuição das áreas de recarga para futuras medidas conservacionistas. Os resultados 
DIAS, N. W.; DINIZ, H. N.; TARGA, M. S.; BATISTA, G. T. Geospatial technology applied to the identification of groundwater recharge areas in northeastern São Paulo, Brazil. Ambi-Agua, Taubaté, v. 4, n. 2, p. 21-30, 2009. (doi:10.4136/ambi-agua.83)

mostram a distribuição de cinco categorias de áreas com potencial de recarga com base na análise das características dos lineamentos, concentração de fraturas e densidade de fraturas. As três categorias superiores devem ser consideradas como detentoras de alta qualidade de percolação e capacidade de infiltração, portanto possuem potencial para a recarga do aquífero. Resultados significativamente diferentes foram obtidos para as duas principais porções da área de estudo, das rochas cristalinas e do material sedimentar inconsolidado. Este fato impossibilitou o estabelecimento de correlações hidrogeológicas para a bacia como um todo. Os resultados devem auxiliar os gestores de recursos hídricos da região no desenvolvimento e implantação de um zoneamento de proteção do aquífero e em atividades de educação ambiental e intervenções conservacionistas pelas comunidades locais.

Palavras-chave: recarga de aquíferos; hidrogeologia regional; conservação de água; sensoriamento remoto.

\section{INTRODUCTION}

Brazil holds one of the largest freshwater reserves in the world accounting for approximately $12 \%$ of Earth's available freshwater. After the 1950s, Brazil has experienced fast urban and population growths that has caused devastating impacts on its water resources, especially in the south and southeast regions were the population growth process was more dramatic due to natural growth and internal migration. Causes of this degradation are associated mainly with both pollution and erosion processes, the first caused by uncontrolled and untreated sewage and industrial discharges and the second with land cover changes due to extensive agriculture expansion.

During the 1980s, the Federal Government tried to cease this devastating process by creating new policies and legislation. Most of those top-down initiatives had little effect. The most important outcome of that period was the new Constitution of 1988, which determined in its Articles 20 and 26 that water resources are a public asset. Therefore, the new Constitution blocked new initiatives to privatize water resource use in the country. Another important legal instrument was Resolution 20 established in 1986 by the National Council of the Environment (Brasil, 1986) that defined a hierarchical classification of water bodies and a set of limiting concentrations of water quality parameters. These water quality standards were revised by CONAMA in its Resolution 357 published in 2005 (Brasil, 2005). Even though these top-down measures were received with high hopes by the government, they produced little impact in terms of changing the way the Brazilian society related with its water resources. During the 1990s Brazil started a government decentralization process that produced some positive outcomes. One of those outcomes was the establishment of a new legal framework by the National Water Resource Policy initiated in 1997. As a result Paraíba do Sul Hydrographic Basin Committee (CBH-PS) was created and grassroots initiatives began to have a forum for debate and a source of investment in local and regional issues related to water resource conservation and preservation.

The development process of Paraíba do Sul river valley, in the second half of the last century, focused on intensive industrial activities and urban population growth caused by increased water resource degradation. According to Coimbra et al. (apud Dias et al., 2007), this degradation is the result of approximately one billion litters of non-treated sewage released daily directly into the river, since $90 \%$ of the municipalities in the basin have no sewage treatment plants capable of reducing the organic load released to the river. On top of the daily urban load, there is also 150 tons of BOD (Biologic Oxygen Demand) released by organic industrial discharges. The estimated total organic load is 330 tons of BOD per day for 
DIAS, N. W.; DINIZ, H. N.; TARGA, M. S.; BATISTA, G. T. Geospatial technology applied to the identification of groundwater recharge areas in northeastern São Paulo, Brazil. Ambi-Agua, Taubaté, v. 4, n. 2, p. 21-30, 2009. (doi:10.4136/ambi-agua.83)

the São Paulo portion of the basin (approximately 13,900 $\mathrm{km}^{2}$ ), from which $55 \%$ percent comes from urban and $45 \%$ from industrial discharges.

The combination of surface water quality degradation and increased demand for water sources by the industry and urban water supply companies has put additional pressure on groundwater reserves. This fact was a cause of concern by CBH-PS since there was little knowledge about the status of groundwater reserves in the region. One of the concerns was the lack of knowledge about the location of groundwater recharge areas considering the increasing urban and industrial growth in the basin. Therefore, there was a need to identify and describe the groundwater recharge areas within the basin in order to develop more appropriate plans for the protection of those areas to improve recharge.

Previous research produced a reasonable knowledge about the geologic context of Paraíba do Sul river basin based on field surveys and applied research. The central portion of the basin is an intergranular aquifer comprised of unconsolidated material originated from alluvial deposits along the river channel. "The Middle Valley of Paraíba do Sul River shows geologic and hydrogeologic important anomalies if compared to the rest of the State of São Paulo. Taubaté basin, formed by neotectonic reactivations, is the main responsible for such characteristics. These aquifers are heterogeneous and anisotropic. The hydraulic flows percolate in the direction of Paraíba do Sul River main channel. In this area, the flow is interrupted by the hydrogeologic abrupt contrast in the fractured border of the horst, causing accumulation and mixing of water. These characteristics are enhanced by the potentiometric gradient of groundwater exploration" (Anjos and Diniz, 2006).

The hydrogeology of the outskirts of Taubaté basin is dominated by fractured aquifers where research aimed at describing its characteristics is not as extensive. These aquifers are characterized by negligible primary porosity with faulting, fracturing, and jointing zones responsible for controlling groundwater movement (Xu and Usher, 2006). Groundwater flow in this context is limited by fracture density since these features can promote conduit flow. As fracture density increases the system becomes increasingly porous. In order to describe such systems, data on fracture length, orientation, aperture, and density should be gathered (Vance, 1994). In areas with considerable extent, scarce geologic information, and comprised of igneous and metamorphic rocks the location of water holding fractures becomes a very complex endeavor because of the need for geostructural, hydrogeologic, and geophysical information (Soares et al. 2008).

The objective of this research was to locate and describe the geographic distribution of groundwater recharge areas in the state of São Paulo portion of Paraíba do Sul river basin in southeastern Brazil. To achieve this goal, specific objectives were defined as follows: development of a physical characterization of the study area based on the visual interpretation of Landsat TM data; generation of a map describing the morphostructural and hydrogeologic conditionings in the area; generation of a map representing the structural lineaments; generation of a slope map of the area; evaluation of the hydrogeologic characteristics of the area based on existing well records; and integration of all results to identifying groundwater recharge areas.

\section{DATA AND METHODS}

A considerable amount of existing hydrogeologic data was obtained from private well perforation companies and from the Department of Water and Energy of the State of São Paulo (DAEE). A georreferenced database was developed for this study and comprised of several layers of geospatial information produced from existing hydrogeologic data and 
DIAS, N. W.; DINIZ, H. N.; TARGA, M. S.; BATISTA, G. T. Geospatial technology applied to the identification of groundwater recharge areas in northeastern São Paulo, Brazil. Ambi-Agua, Taubaté, v. 4, n. 2, p. 21-30, 2009. (doi:10.4136/ambi-agua.83)

additional information derived from the interpretation of satellite data obtained from visible and infrared bands of the TM sensor on board of Landsat-5.

Image interpretation was performed in two Landsat TM scenes acquired on September 2000 (path and roll 219/076 and 218/076). A Digital Elevation Model (DEM) was produced using Shuttle Radar Topographic Mission (SRTM) data acquired in 2000 in the following quadrants: $\mathrm{S} 23^{\circ} \mathrm{W} 45^{\circ}, \mathrm{S} 23^{\circ} \mathrm{W} 46^{\circ}, \mathrm{S} 24^{\circ} \mathrm{W} 45^{\circ}, \mathrm{S} 24^{\circ} \mathrm{W} 46^{\circ}$. Additional information was obtained from IBGE (Brazilian Institute of Geography and Statistics) topographic maps; existing geology, geomorphology, and hydrogeology charts; and existing data reprocessed by the following software packages SPRING 4.1, ARCVIEW 3.2, AUTOCAD MAP 2000, SURFER 8.0, VISUAL GROUNDWATER, and BALASC.

The data, both existing and generated, were adjusted to the 1:100,000 scale. Additional existing data were added to the analysis including geologic data from Kurdkdjian et al. (1992) and IBGE (1986), geotechnical and geomorphologic maps from IPT - Institute of Technologic Research (1981), and hydrogeologic data from DAEE (1977). The stream network of the study area was developed based on existing digital hydrographic maps in 1:50,000 scale that were post-processed in order to build individual stream channel connections and the final stream network for the entire basin.

The research was followed by an interdisciplinary procedure implemented with the goal of identifying and characterizing the groundwater recharge areas. The first phase of this procedure involved the weighting of several aspects associated the static and dynamic characteristics of the physical environment, such as geology, geomorphology, hydrology, and geotectonism. This information, once integrated and interpreted, led to the identification and characterization of different compartments and environments that included both intervention and adjacent areas. In the second phase of the interdisciplinary approach it was implemented a both analytical (diagnostic) and systemic (integration, prognostic, and synthesis) analysis that sought to emphasize the dynamic aspects that emerges from the interdependence of the different components.

Image interpretation followed a logic and systematic analysis of the texture elements as described by Veneziani and Anjos (1982). This approach is based on metric and geometric relations along with the structuring degree and order of the textural elements associated with relief and drainage, and analyzed by inductive and deductive processes (Coelho Neto, 2003).

The detailed characterization of the study area for the aspects associated with geomorphology, morphodynamic characteristics, regional geology, structural geology, and hydrogeologic conditioning morphostructures is available in Anjos and Diniz (2006).

\section{RESULTS AND DISCUSSION}

The fracture density map presented in Figure 1 was produced by the identification of fractures extracted from the drainage network layer. This information was generated from GIS (Geographic Information System) analysis in a 1:100,000 scale and applying a $25 \mathrm{~km}^{2}$ grid for the analysis. This map shows areas, or zones, with similar secondary relative porosity and groundwater recharge/discharge potentials. Density value was calculated based on the number of fracture features found in $5 \times 5 \mathrm{~km}$ cells. The calculated density value was then applied to the central node of each sampled cell. Density calculations and cell node attributed values were applied to all same size cells until the entire study area was covered. Then a GIS interpolation analysis was performed with a total of 48,000 fracture features by applying kriging analysis. Four relative fracture density classes were produced along with contour line generation. The analysis of relative fracture density data was the basis for identifying the axes 
DIAS, N. W.; DINIZ, H. N.; TARGA, M. S.; BATISTA, G. T. Geospatial technology applied to the identification of groundwater recharge areas in northeastern São Paulo, Brazil. Ambi-Agua, Taubaté, v. 4, n. 2, p. 21-30, 2009. (doi:10.4136/ambi-agua.83)

of maximum fracturing. Additional refinement of this analysis was implemented by categorizing the fracture feature population into six tectonic directions: $\mathrm{N} 15^{\circ}-35^{\circ} \mathrm{W} ; \mathrm{N} 35^{\circ}$ $55^{\circ} \mathrm{W} ; \mathrm{N} 45^{\circ}-65^{\circ} \mathrm{E} ; \mathrm{N} 80^{\circ} \mathrm{W}-\mathrm{N} 80^{\circ} \mathrm{E} ; \mathrm{N} 10^{\circ} \mathrm{E}-\mathrm{N} 10^{\circ} \mathrm{W}$; and $\mathrm{N} 15^{\circ}-35^{\circ} \mathrm{E}$.

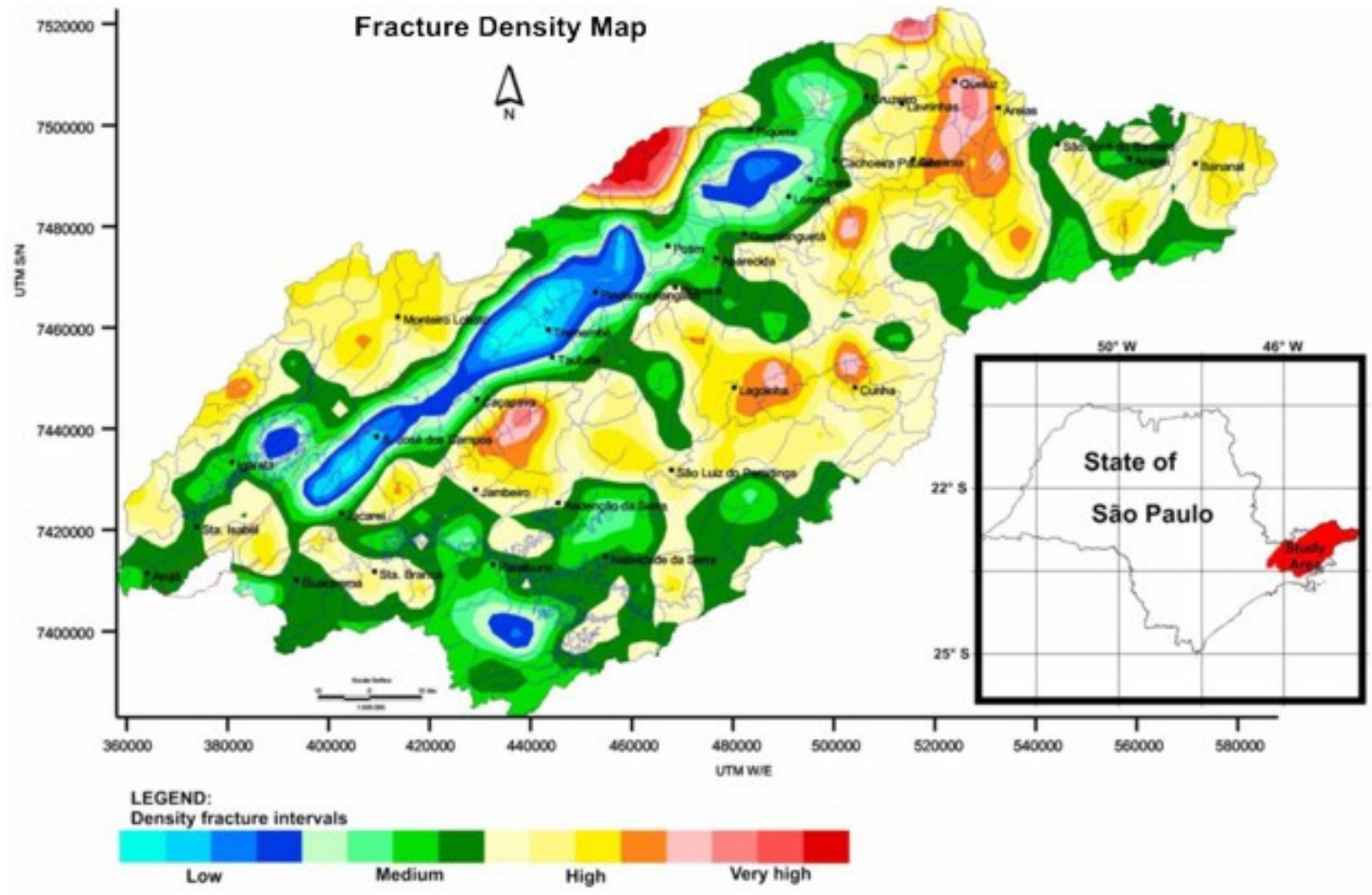

Figure 1. Fracture density map shown in density intervals. Location of the study area shown in the smaller map presented in the bottom right corner of the figure.

The recharge area and groundwater flow map was produced from the interpretation of preliminary maps, such as the map of hydrogeologic conditionings generated from the analysis of both drainage and structural lineament maps. The map was designed based on the identification of symmetric relations between consequent and obsequent drainage channels and the delineation of structural contour lines without known level in the study area. A second map was generated to illustrate groundwater flow by following the technique described by Veneziani et al. (1993). In this technique the association between flexural folding and distensive movements can provide information about the distribution of groundwater along the structural heights and lows indicating some aspects of the groundwater flow behavior in a specific region. The resulting map is presented in Figure 2.

Based on this map, a relative synthesis of morphostructural recharge areas was developed. The result was the identification of the main recharge areas (those with divergent discordant flow), discharge areas (with convergent discordant flow), and concordant (with unidirectional flow).

A total of 16 recharge areas were identified with this procedure. These areas are characterized by elongated features with their main direction oriented toward NE, parallel to the geologic structuring of the area and to the elongated litho-structural units.

Hydrogeologic analysis of perforated well records was divided in two sub-regions of the study area due to the spatial concentration of wells in the southwestern portion of the area. A total of 368 wells, with appropriate records, were located in the Taubaté sedimentary basin and were used for this analysis. Potentiometric level was obtained by the difference between the well level and the water table. The water table information of wells is recorded at local municipality offices and were interpolated using Surfer 8.0. An equal-potential contour line map (Figure 3) was generated for the entire study area taking into account differences of 
DIAS, N. W.; DINIZ, H. N.; TARGA, M. S.; BATISTA, G. T. Geospatial technology applied to the identification of groundwater recharge areas in northeastern São Paulo, Brazil. Ambi-Agua, Taubaté, v. 4, n. 2, p. 21-30, 2009. (doi:10.4136/ambi-agua.83)

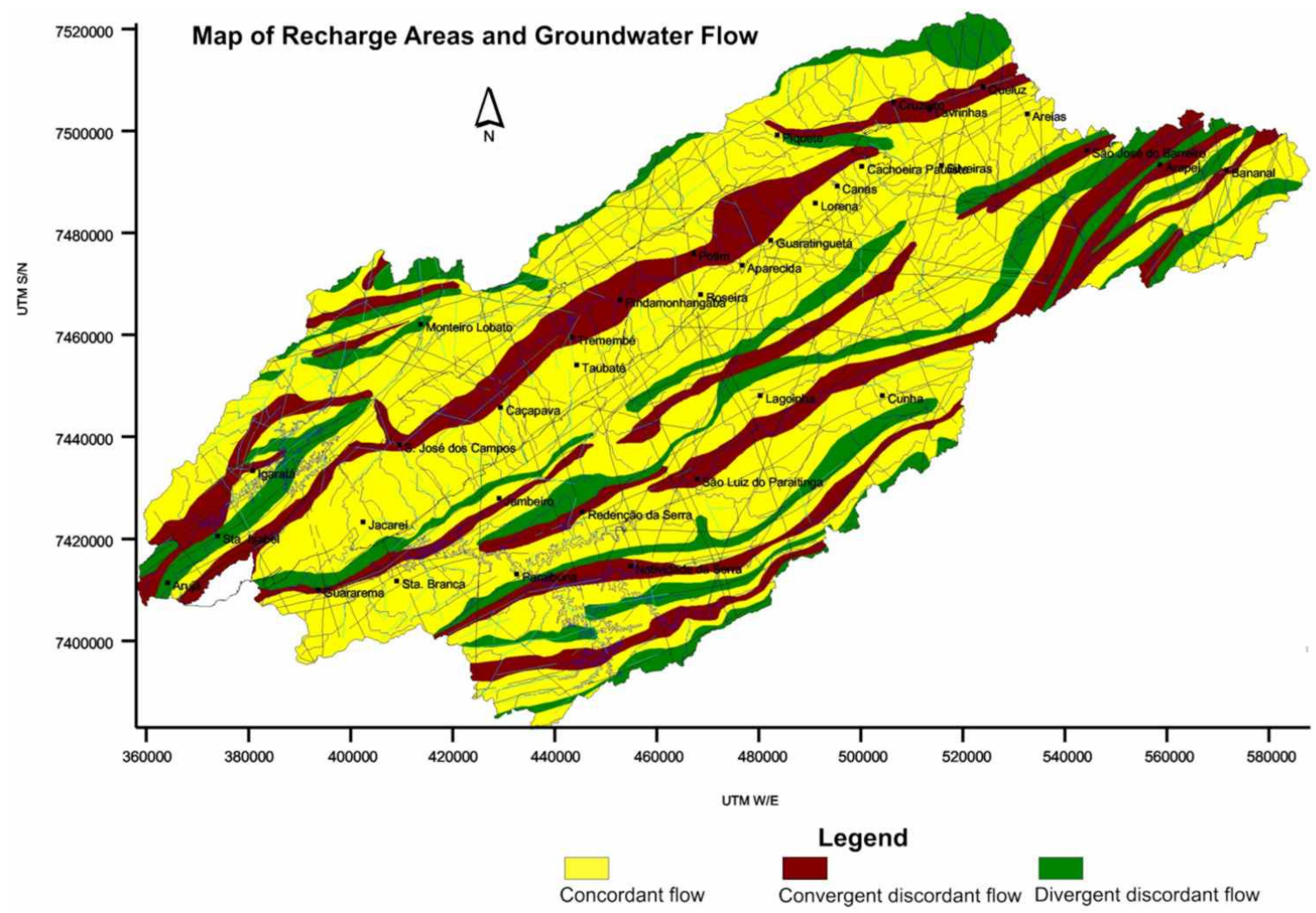

Figure 2. Location of convergent discordant flow (recharge areas) and the other two categories of groundwater flow (concordant and divergent discordant).

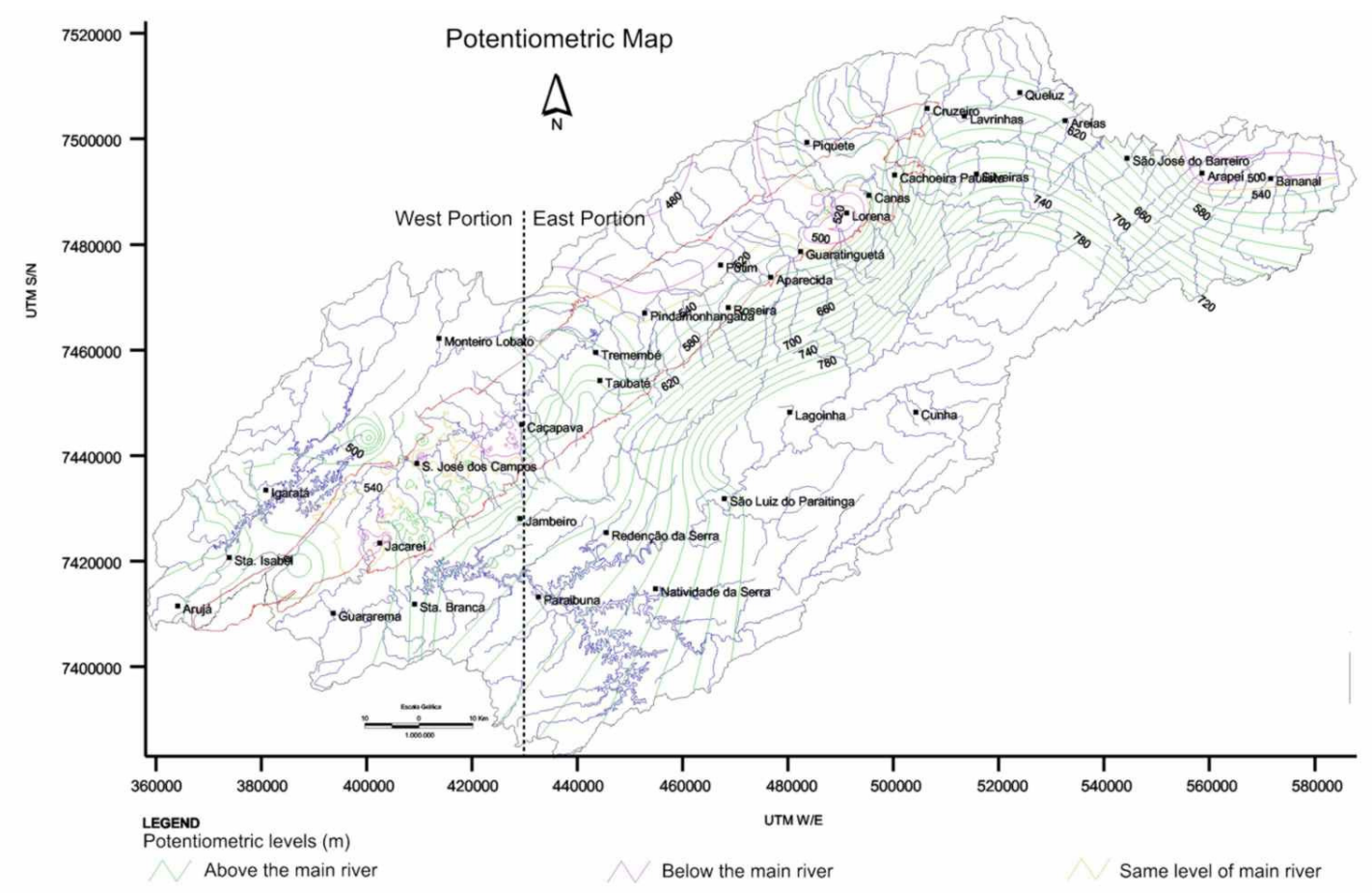

Figure 3. Potentiometric map of the study area showing groundwater levels in relationship to Paraíba do Sul river channel base level.

sampling densities in both compartments. The map shown in Figure 3 demonstrates that groundwater flow tends to converge toward Paraíba do Sul main channel from the surrounding higher elevation areas (Mantiqueira Mountain Chain in the north and Jambeiro 
DIAS, N. W.; DINIZ, H. N.; TARGA, M. S.; BATISTA, G. T. Geospatial technology applied to the identification of groundwater recharge areas in northeastern São Paulo, Brazil. Ambi-Agua, Taubaté, v. 4, n. 2, p. 21-30, 2009. (doi:10.4136/ambi-agua.83)

and Quebracangalha Mountain Chains in the south). The average groundwater level at the river valley municipalities of São José dos Campos, Jacareí, and Caçapava is approximately $540 \mathrm{~m}$. In the municipality of Lorena (northeastern portion downstream) the average level is $510 \mathrm{~m}$.

The analysis of equal-potential contour lines shows that the river channel has a water table level lower than the river's base level. This finding indicates that the river influences groundwater recharge by providing surface water to the aquifer when the river water level is higher than the aquifer surface level and where the river bed is made of permeable material. These results are similar to the findings of DAEE (1977) and reinforce the theory that the river is an influent agent in groundwater recharge in most of its course near the municipality of São José dos Campos as well as near Lorena in the northeastern portion of the area. Influent rivers such as Paraíba do Sul are common in semi-arid regions; therefore this behavior is not expected in the southeastern region of Brazil. This behavior indicates that groundwater pumping through deep tubular wells in operation in the Paraíba do Sul river valley, since the 1930s, may be inducing groundwater recharge from surface watercourses that infiltrate water in their beds and further percolates supplying additional water to the sedimentary aquifer.

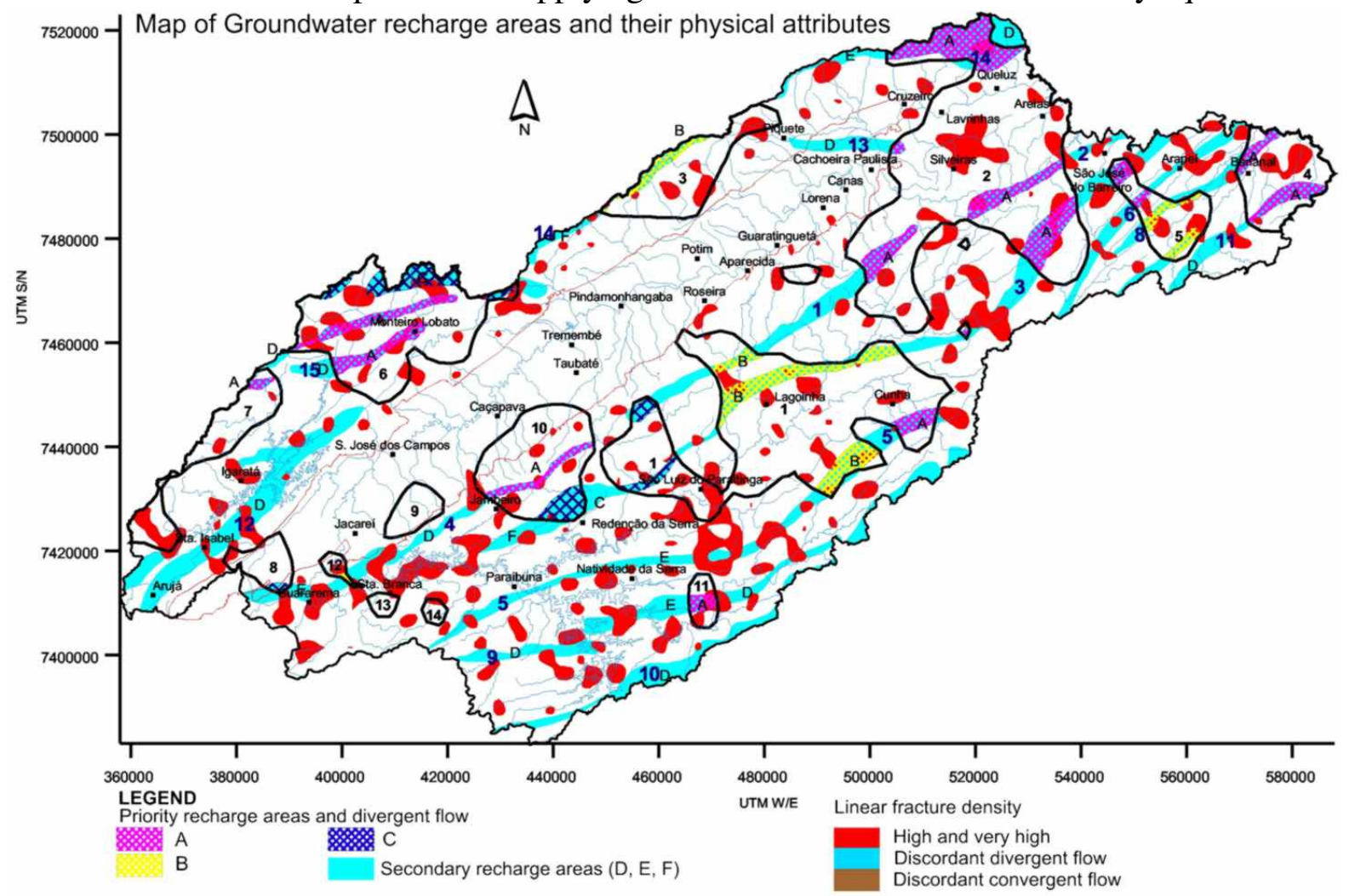

Figure 4. Map showing the product of the final analysis of the recharge areas identified by GIS analysis and multi-criteria weighting analysis.

In other portions of the study area, such as near the municipalities of Taubate and Tremembé, the equal-potential contour lines show higher base level values, indicating that the river receives water from the aquifer. This is a more common behavior in humid climates, such as in the region where the study took place.

The areas where high fracture densities were found, further analyses were conducted in order to analyze their general density characteristics, specific directions, and, then, identify axes of maximum fracturing. These areas were then correlated to Riedel (1929) deformation model that defines bundles of fracturing. The correlation of areas with high fracture densities and the frequency of fracture bundles was determinant in describing the 16 previously selected recharge areas in terms of their hydrogeologic potential. Figure 4 shows the final result with a 
DIAS, N. W.; DINIZ, H. N.; TARGA, M. S.; BATISTA, G. T. Geospatial technology applied to the identification of groundwater recharge areas in northeastern São Paulo, Brazil. Ambi-Agua, Taubaté, v. 4, n. 2, p. 21-30, 2009. (doi:10.4136/ambi-agua.83)

total of 11 areas identified as having the higher densities. These areas were further divided by the number of fracture bundles existing in each area. A weighting scale using weights 1,2 , and 3 was adopted for classifying each area.

The areas with most interaction among lineament characteristics (lineament density and crossings), fracture bundles, and higher fracture densities, were the ones to be considered as areas with higher percolation quality and infiltration capacity, therefore areas with higher potential for groundwater recharge.

A final recharge map (Figure 5) showing the study area subdivided in five categories of groundwater recharge capacity was produced by reclassifying the recharge units presented in Figure 4 and groundwater potentiometric information (shown in Figure 3) for the sedimentary basin.

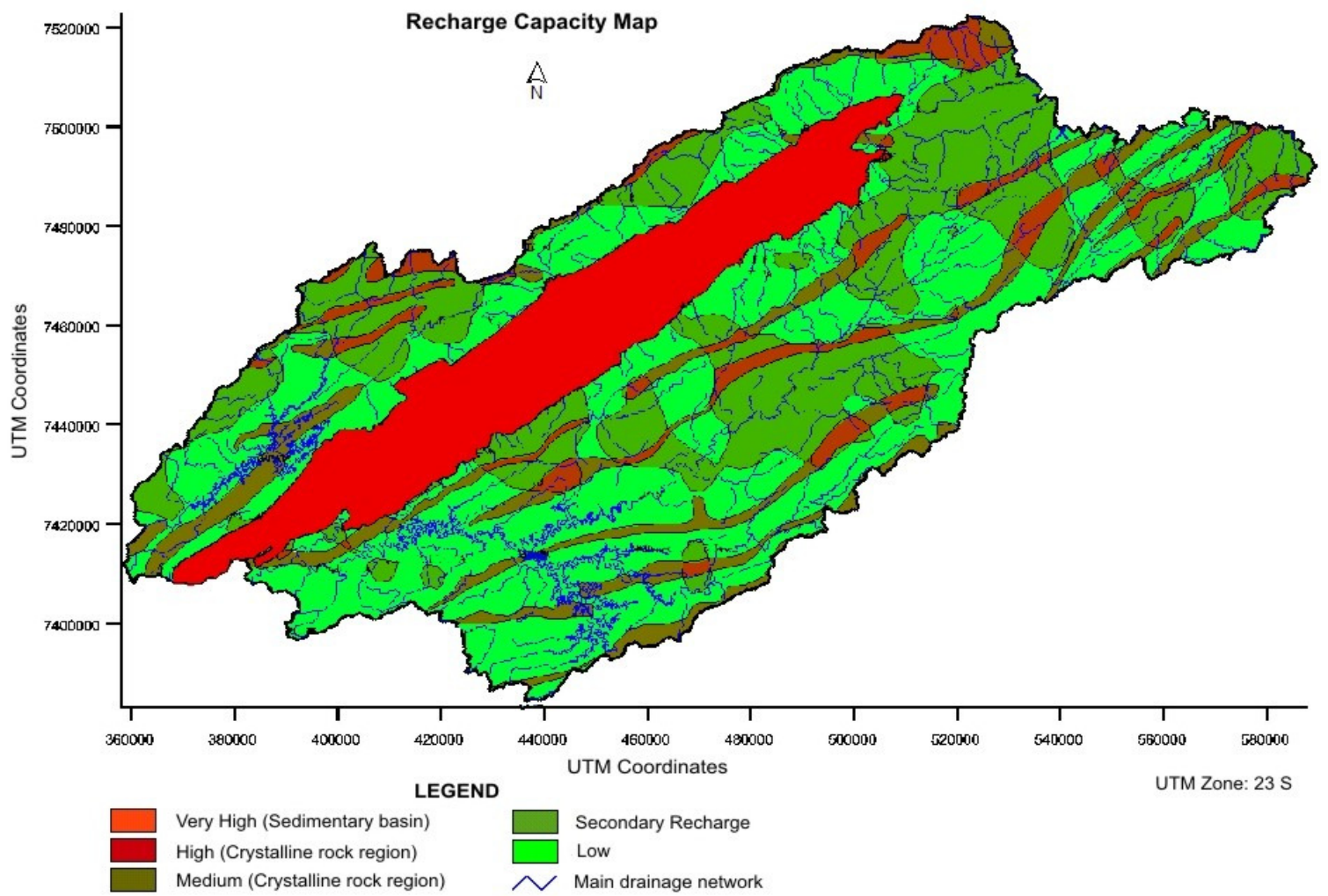

Figure 5. Recharge capacity map of the study area.

Therefore, the five ranked categories (from Very High to Low) represent portions of the study area that should get special attention from regional water resource managers for future planning and intervention initiatives aiming at protecting the top three categories from land use and land cover practices that could damage their groundwater recharge potential. This information could also initiate a discussion among those managers for developing an aquifer protection zoning program for the entire Paraíba do Sul river basin.

\section{CONCLUSIONS}

The analysis implemented in this research, based on the convergence of evidence and on the integration of information derived from different spatial correlation analyses, generated results that allowed to identify areas that show attributes highly associated with recharge and discharge properties in the Paraiba do Sul river valley in the northeastern portion of the State of São Paulo. The correlation between discordant convergent and high fracture density areas allowed identifying portions of the study area with higher potential for groundwater recharge. 
DIAS, N. W.; DINIZ, H. N.; TARGA, M. S.; BATISTA, G. T. Geospatial technology applied to the identification of groundwater recharge areas in northeastern São Paulo, Brazil. Ambi-Agua, Taubaté, v. 4, n. 2, p. 21-30, 2009. (doi:10.4136/ambi-agua.83)

This research presented significantly different results for the two major portions of the study area, crystalline rocks and unconsolidated sedimentary material. In the crystalline rock region the method applied (interpretation of remote sensing data) showed a better performance in terms of generating information about structural and tectonic geology as well as the physical characterization (relief, drainage, and slope attributes) of the study area. This fact led to a more straightforward identification of recharge and discharge areas. However, determining the hydrodynamic behavior in this region was limited due to the high spatial variation of geologic and structural parameters and characteristics. This variation did not allow the determination of significant hydrogeologic correlations at a regional scale.

In the sedimentary basin there is a lower dependency of groundwater recharge to fracture systems due to the predominance of more homogeneous units with large lateral extent. This characterization, however, was optimized by the analysis of deep well records. The results indicate that the sedimentary basin region is the most important groundwater recharge area within the river valley.

The results may be used for supporting water resource management decisions by the Hydrographic Basin Committee targeting at new groundwater conservation policies, such as the development and implementation of an aquifer protection zoning program for the river basin, as well as supporting local community activities in environmental education and conservationist interventions.

\section{AKNOWLEDGEMENTS}

Authors want to thank the State of São Paulo Fund for Water Resources (FEHIDRO) and the Paraíba do Sul Hydrographic Basin Committee (CBH-PS) for the financial support of this research and Celso S. Catelani for his support in developing the final maps.

\section{REFERENCES}

ANJOS, C. E.; DINIZ, H. N. Caracterização de áreas de recarga com análise integrada de dados orbitais TM Landsat e dados hidrogeológicos: região do Médio Vale do Rio Paraíba do Sul, Estado de São Paulo. São José dos Campos: MC Geologia e Meio Ambiente, 2006. 160 p.

COELHO NETTO, A. L. Evolução de cabeceiras de drenagem no médio Vale do Rio Paraíba do Sul (SP/RJ): a Formação e o crescimento da Rede de Canais sob Controle Estrutural. Revista Brasileira de Geomorfologia, v. 2, p. 69-100, 2003.

BRASIL. Ministério do Meio Ambiente. Conselho Nacional de Meio Ambiente - CONAMA 1986. Resolução CONAMA No. 20, de 18 de Junho de 1986. Diário Oficial da União de 30 de julho de 1986. Brasília: MMA, 1986.

BRASIL. Ministério do Meio Ambiente. Conselho Nacional de Meio Ambiente - CONAMA. 2005. Resolução no 357 - Dispõe sobre a classificação dos corpos de água e diretrizes ambientais para o seu enquadramento, bem como estabelece as condições e padrões de lançamento de efluentes. Diário Oficial da União de 17 de Março de 2005. Brasília: MMA, 2005.

DEPARTAMENTO DE ÁGUAS E ENERGIA ELÉTRICA - DAEE. Estudo de águas subterrâneas: região administrativa 3 - S. J. dos Campos e faixa litorânea. São Paulo: Enco/DAEE, 1977. 112 p.. Vol. 1. 
DIAS, N. W.; DINIZ, H. N.; TARGA, M. S.; BATISTA, G. T. Geospatial technology applied to the identification of groundwater recharge areas in northeastern São Paulo, Brazil. Ambi-Agua, Taubaté, v. 4, n. 2, p. 21-30, 2009. (doi:10.4136/ambi-agua.83)

DIAS, N. W.; MORAES, E. C.; NOVO, E. M. L. M.; ARAI, E.; CATALANI. C. S. Caracterização das águas da Represa de Paraibuna com o uso de dados hiperespectrais. In: SIMPÓSIO BRASILEIRO DE SENSORIAMENTO REMOTO, 13., 21-26 abril 2007, Florianópolis. Anais... São José dos Campos: INPE, 2007. p. 3335-3342.

INSTITUTO BRASILEIRO DE GEOGRAFIA E ESTATÍSTICA - IBGE. Levantamentos de recursos naturais. Rio de Janeiro: IBGE, 1986. Vol. 26.

INSTITUTO DE PESQUISAS TECNOLÓGICAS DO ESTADO DE SÃO PAULO - IPT. Mapa geomorfológico do estado de São Paulo. São Paulo: IPT, 1981. 94p. (Monografias 5- $\mathrm{n}^{\circ} 1183$ ).

KURKDJIAN, M. L. N. O; VALÉRIO FILHO, M; VENEZIANI , P.; PEREIRA, M. N.; FLORENZANO, T. G.; ANJOS, C. E. et al. Macrozoneamento da Região do Vale do Paraíba e Litoral Norte do estado de São Paulo. São José dos Campos: INPE, 1992. 176 p. (INPE- 5381-prp/165).

RIEDEL, W. Zur mechanik geologischer bucherscheinungen. Central bl. f. Blatt F. Min. Geol. Und. Pal., v. 8, p. 354-368, 1929.

SOARES, P. V.; PEREIRA, S. Y.; SIMÕES, S. J. C.; BERNARDES, G. P.; BARBOSA, S. A. Mapa de infiltração do alto e médio Vale do Paraíba do Sul com base em elementos do meio físico e na precipitação. Ambi-Agua, Taubaté, v. 3, n. 1, p. 26-42, 2008. (doi:10.4136/ambi-agua.40)

VANCE D, B. 2 The 4 Technology Solutions: Anisotropic Hydrology - Part I - Fracture Flow Systems. National Environmental Journal, v. 4, n. 4, p. 25-26, jul./ago. 1994. Available in: <http://2the4.net/anisofrac.htm>. Access on aug. 2009.

VENEZIANI, P.; ANJOS, C. E. Metodologia de interpretação de dados de sensoriamento remoto e aplicações em geologia. São José dos Campos: INPE, 1982. 54p.

VENEZIANI, P.; ANJOS, C. E.; NASCIMENTO, F. M. F.; BIGNELLI, P. A.; DIAS, R. R. Reconhecimento de figuras de interferência geradas pela superposição de dobras flexurais na região do vale do Paraíba do Sul (SP) com a utilização de sensoriamento remoto. IN: Simpósio Brasileiro de Sensoriamento Remoto, 7. (SBSR), 1993, Curitiba, BR. Anais... São José dos Campos: INPE, v. 3, p. 368-375, 1993.

XU, Y.; USHER, B. Issues of groundwater pollution in Africa. In: XU Y.; USHER, B. (Eds.) Groundwater pollution in Africa. London: Taylor \& Francis, 2006.p 3-9. 